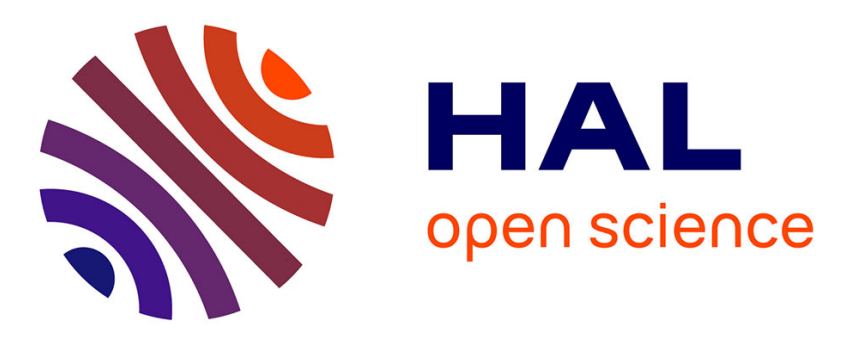

\title{
Pliocene Bovidae (Mammalia) from the Koro Toro Australopithecine sites, Chad
}

Denis Geraads, Michel Brunet, Hassan T. Mackaye, Patrick Vignaud

\section{To cite this version:}

Denis Geraads, Michel Brunet, Hassan T. Mackaye, Patrick Vignaud. Pliocene Bovidae (Mammalia) from the Koro Toro Australopithecine sites, Chad. Journal of Vertebrate Paleontology, 2001, 21 (2), pp.335-346. halshs-00068080

\section{HAL Id: halshs-00068080 \\ https://shs.hal.science/halshs-00068080}

Submitted on 10 May 2006

HAL is a multi-disciplinary open access archive for the deposit and dissemination of scientific research documents, whether they are published or not. The documents may come from teaching and research institutions in France or abroad, or from public or private research centers.
L'archive ouverte pluridisciplinaire HAL, est destinée au dépôt et à la diffusion de documents scientifiques de niveau recherche, publiés ou non, émanant des établissements d'enseignement et de recherche français ou étrangers, des laboratoires publics ou privés. 
PLIOCENE BOVIDAE (MAMMALIA) FROM THE KORO TORO AUSTRALOPITHECINE SITES, CHAD

DENIS GERAADS ${ }^{1}$, MICHEL BRUNET $^{2}$, HASSAN T.MACKAYE $^{3}$, and PATRICK VIGNAUD $^{2}$

${ }^{1}$ UPR 2147 CNRS, 44 rue de l'Amiral Mouchez, 75014 Paris, France;

${ }^{2}$ Laboratoire de géobiologie, biochronologie et paléontologie humaine, EP 1596, UFR SFA, Université de Poitiers, 40 avenue du recteur Pineau, F-86022 Poitiers Cedex, France;

${ }^{3}$ University of N'Djaména, Chad

Running title: GeraAds ET AL. - PlioCene Bovids From ChAD

Denis GERAADS: $\quad$ phone 33143135621 (office); 33148863208 (home)

fax 331431356 30; e-mail dgeraads@ivry.cnrs.fr 
Abstract -The Australopithecus-bearing sites of Koro Toro in central Chad yielded at least 9 species of bovids (Ruminantia: Bovidae). They all belong to genera found in North and/or East Africa, but three new species are named. Kobus korotorensis n. sp. is quite distinct from East African species, and is probably an early offshoot from primitive Reduncines. Kobus

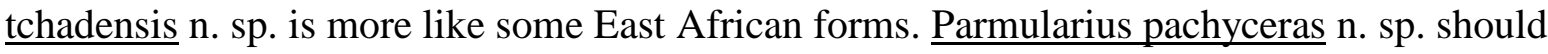
rather be compared with a North African species. This relative endemism hinders precise biochronological correlation, but the best fit is in the range $2.7-3.4 \mathrm{Ma}$. The lack of Tragelaphines, and an abundance of Reduncines, Alcelaphines and Antilopines definitely points towards an open environment, that was drier than most East African sites of this age. 


\section{INTRODUCTION}

A number of fossil localities were discovered by the "Mission Paléontologique FrancoTchadienne" in central Chad; ages range from earliest Pliocene (Brunet et al., 1998) to Pleistocene (unpublished localities). Some of the localities are famous for having yielded a new species of Australopithecus, A. bahrelghazali Brunet et al., 1996. Locality 12 of Koro Toro (KT12) has yielded the type of this hominid species. KT13 has yielded yet another hominid specimen (Brunet et al., 1997). Here we describe the bovids from these localities, as well as specimens from other sites in the same area (KT33 and KT4b; map, Fig. 1), likely to be of similar age.

The Koro Toro area is flat and desertic. Fossiliferous localities are areas varying in size from a few hundred square meters at KT33 to more than 100,000 $\mathrm{m}^{2}$ at KT13. All localities contain surface fossils, but several test excavations indicate that the density of fossils is low within the sediment. The stratigraphic relationships between localities cannot be determined in the field, and age determinations are based upon biochronology. On biochronological grounds, KT 12 and KT 13 have been estimated to be in the time range 3-3.5 Ma (Brunet et al., 1997). Thus, they would be roughly contemporaneous with the Sidi Hakoma and Denen Dora Members of the Hadar Formation in Ethiopia; Members A - B of the Shungura Formation, also in Ethiopia; the Lokochot and Tulu Bor Members of the Koobi Fora Formation in Kenya; and with Laetoli in Tanzania.

In the descriptions below, we follow Gentry and Gentry's classification of the Bovidae (1978). The use of “cf.” and "aff." follows Matthews (1973) and Lucas (1986), "aff." meaning “close to, but different", "cf.” meaning "perhaps identical, but diagnostic elements missing”. Measurements are in millimeters. Those measurements in brackets following horn-cores are the greatest antero-posterior diameter (long axis of cross section) at base, and transverse 
diameter, perpendicular to the former. A goat fold is a fold of enamel at the antero-mesial corner of lower molars; a frontlet is a pair of horn-cores attached to the frontal bone;

clockwise/anticlockwise refer to the direction of spiralling of a horn-core, seen from its tip or base (e.g., it is clockwise in DNA). All fossils are kept in the "Centre National d'Appui à la Recherche », BP 1228, N’Djamena, Chad.

\section{SYSTEMATIC PALEONTOLOGY}

Class Mammalia

Order Artiodactyla

Family Bovidae

Tribe Bovini

Genus Simatherium Dietrich, 1941

\section{Cf $\underline{\text { Simatherium sp. }}$}

Material-- KT13-96-24: upper molar; KT13-96-197: mandible with m2-m3; KT13-96207: mandible with p4-m2 (Fig. 2A); KT13-96-251: proximal radius; KT13-95-3: astragalus; KT13-95-5: astragalus; KT12, no n: lower molar; KT12, no nº: upper molar; KT33-96-2: upper molar; KT33-96-3: upper molar; KT33-96-25: m3; KT33-96-44: lower molar. The material from KT13 was identified as Bovini indet., cf. Syncerus in Brunet et al. (1997).

This tribe is represented only by teeth and a few limb-bones. Nothing suggests that more than one species is present. The best specimen is a mandible fragment with $\mathrm{p} 4-\mathrm{m} 2$, KT13-96-207, with little wear (Fig. 2A). The p4 is almost as long as m1, and the premolar series was certainly not much reduced, a primitive character. However, p4 is much evolved for a bovine, in that the metaconid is elongated as a medial wall, though it fails to meet the paraconid and entoconid. This trend towards molarisation of p4 is typical of African Bovini (Gentry, 1967, 1985; Gentry and Gentry, 1978). In the Turkana basin, this morphology would 
better fit a latest Pliocene or Pleistocene age, but a molarized p4, doubtfully referred to

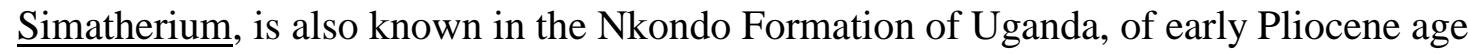
(Geraads and Thomas, 1994), and the p4 of Simatherium demissum Gentry, 1980 from the Mio-Pliocene of Langebaanweg in South Africa is not much more primitive than that of KT13-96-207.

Molars from KT12, KT13, and KT33 also have a rather derived occlusal pattern. Pillars of the main tubercles are antero-posteriorly pinched, especially the buccal lobes of lower molars and lingual lobes of upper ones. Accessory columns are present on all teeth, but are not very strong nor complicated. Buccal walls of upper molars and lingual ones of lower molars have outbowings which are less strong and localized than in modern $\underline{\text { Syncerus. }}$

The Koro Toro bovine does not easily fall into the classification of African Bovini. Gentry (1978) and Vrba (1987) argued for a late Miocene splitting of two lineages, one leading from $\underline{\text { Simatherium }}$ to Pelorovis, the other from $\underline{\text { Ugandax }}$ to $\underline{\text { Syncerus. }}$. In the Pliocene,

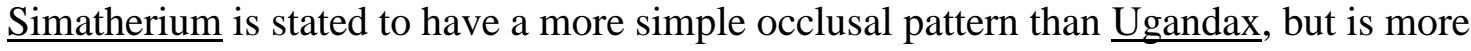
derived by its shorter premolars and more molarized p4 (Gentry, 1980: 245). The Koro Toro bovine shows a different mixture of characters, and is perhaps more similar to the Nkondo bovine. The distinction between the supposed Simatherium and Ugandax lineages remains to be further substantiated.

\section{Tribe Hippotragini}

This tribe is represented by an incomplete m3 (KT13-96-182). It is larger and less antero-posteriorly compressed $(\mathrm{L}=36.5 ; \mathrm{W}=15)$ than the reduncine teeth from this locality, and the goat fold is smaller. It differs from the bovine by being smaller, with a more strongly developed goat-fold, and lobes that are less outbowed. Thus, Hippotragini is the most likely identification. 


\section{Tribe Reduncini}

Genus Kobus A. Smith, 1840

Type-species--Kobus ellipsiprymnus (Ogilby, 1833)

The genus, as here understood, is widely accepted to mean only "large reduncine", and a revision of the genus would probably lead to the distinction of several genera.

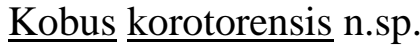

(Fig. 2B, C; Fig. 3E)

Holotype--KT13-95-8 ( $\approx 45$ x 42.5): incomplete left horn-core.

Referred material--KT13-95-11 (41.2 x 40; Fig. 3G), KT13-96-256 (42.3 x 38.3; Fig. 3F): incomplete horn-cores; KT13-96-142: mandible with p3-m2; KT12-96-27 (31.6 x 34.3; Fig. 3I): incomplete horn-core; KT12-98-06 : frontlet (37.8 x 30.3; Fig. 2D,E; Fig. 3J), perhaps of the same species; KT33-96-22 (38.5 x -): base of horn-core; KT4b-96-20 (37 x 36.8; Fig. 3H): incomplete horn-core.

Etymology--The name korotorensis comes from the village of Koro Toro situated near the australopithecine sites.

Diagnosis--A reduncine of medium size. Horn-cores moderately divergent for a reduncine $\left(\approx 60^{\circ}\right)$, with divergence decreasing upwards, strongly inclined backwards, without transverse ridges, with a weak anticlockwise torsion in the right horn, distal part slightly curving forwards, but not hooked. Section at the base little compressed and almost triangular, with a flattened postero-medial face, and a less flattened lateral one. Frontal without sinus; supra-orbital pit opening directly into the orbit. Small post-cornual fossa. Teeth moderately hypsodont.

Description and comparisons--The most diagnostic character of this species is the shape of the cross-section, although it may be less flattened posteriorly at the very base. This 
allows easy identification even from very incomplete horns, such as those from KT4b and KT12 (KT33-96-22 is much eroded and more doubtfully identified). In lateral view, the horncores are not more inclined than the pedicles, they curve backwards for most of their length, but the distal portion was slightly curved forwards, although probably (the extreme tip is missing on all specimens) not hooked as in $\underline{\mathrm{K}}$. ancystrocera from the Turkana basin (Gentry, 1985; Harris et al., 1988; Harris, 1991), K. barbarus from the late Pliocene of Ahl al Oughlam in Morocco (Geraads and Amani, 1998) or Redunca.

The supra-orbital foramen opens at the bottom of the supra-orbital depression directly into the orbit, without any canal through the frontal bone. In this feature, it is clearly distinct from the second species of Kobus found at Koro Toro.

The frontlet KT12-98-06 (Fig. 2D, E) is only doubtfully referred to this species. It shares with $\underline{\mathrm{K}}$. korotorensis the shape of the supra-orbital foramen, course of horn-cores and lack of transverse ridges, but is smaller, and the cross-section is more rounded, like that of

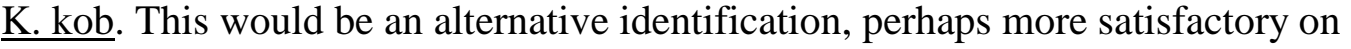
morphological grounds but, in view of the undoubted occurrence of $\underline{\mathrm{K} \text {. korotorensis at KT12 }}$ (horn-core KT12-96-27), it is more parsimonious to assume that it also belongs to the latter species.

KT13-96-142 is the best dental remain that can be referred to this species. All teeth have a typical reduncine morphology, but they are too small to belong to the second species of Kobus. The p4 is not very high, although it is not much worn, and it was therefore less hypsodont than in modern Kobus.

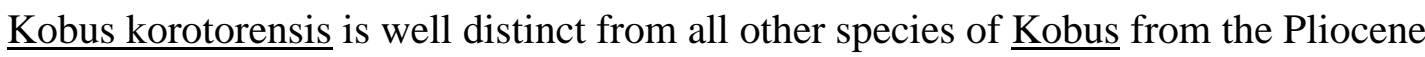
of East Africa. It differs: (1) from Kobus sp. A and ?ํobus ? nov. sp. B from Uganda (Geraads and Thomas, 1994) by the triangular shape of the cross section, and decrease of

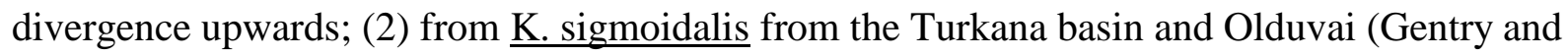


Gentry, 1978) by the triangular shape of the cross section, lesser divergence and lesser transverse compression, smaller distance between the bases, and lack of transverse ridges; (3) from $\underline{K}$. ancystrocera from the Turkana basin by the much less pronounced divergence $\left(\approx 60^{\circ}\right.$ vs $\approx 100^{\circ}$ ), lack of angulation between horn-core and pedicle, lack of transverse ridges and of hooked tip, and weaker transverse compression, but the general course of the horn is a

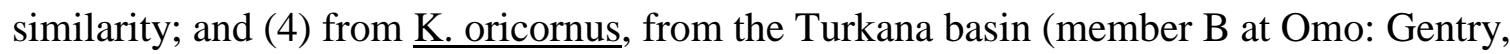
1985; Moiti to Tulu Bor members at Koobi Fora: Harris, 1991), by the much shorter horns , sigmoid curvature and lack of transverse ridges, flattened lateral and postero-medial surfaces, greater transverse compression, but the moderate divergence is a similarity.

In North Africa, K. barbarus also has a tendency to a postero-lateral keel, and the supra-orbital foramen opens directly into the orbit, but the horn-cores are more massive at the base, without torsion, but with increasing divergence distally and strong transverse ridges.

Thus, $\underline{\mathrm{K} . \text { korotorensis }}$ is certainly not closely related to any East or North African species of $\underline{\text { Kobus}}$, which are all much derived in different ways, but some earlier more primitive Reduncines are less distinct: (1) K. subdolus from Langebaanweg shows a tendency towards a flattened postero-medial surface (Gentry, 1980, fig. 20), but the horns are very short (less than $200 \mathrm{~mm}$ ), weakly curved and little divergent, and the teeth are quite primitive; and (2) the Kobus from Lukeino has a much compressed horn-core (Thomas, 1980, fig. 5) but the one from Mpesida has a "section subcirculaire" (Thomas, 1980: 84). An almost circular crosssection is also found in Redunca darti Wells and Cooke, 1956, from Makapansgat, and in the "Redunca aff. darti" from the late Miocene of Sahabi, Libya (Lehmann and Thomas, 1987: 327: "cross-section...almost circular"), and it is likely that this is the primitive condition for Reduncines. 
The Kobus aff. subdolus from Manonga (Gentry, 1997) has slightly compressed horncores, with a flattened lateral surface, a postero-lateral keel, and inconstant transverse ridges, but the post-cornual fossa is deep and the divergence of horn-cores increases upwards.

It is likely that $\underline{\mathrm{K}}$. korotorensis is a specialised offshoot of this early Pliocene group of Reduncines, but the lack of other cranial remains hinders detailed comparisons and phyletic conclusions.

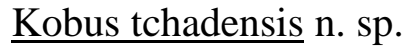

(Fig. 2H, 3A)

Holotype--KT13-96-7, the back part of a cranium with almost complete horn-cores.

Referred material--KT13-96-555: brain-case with detached fragment of horn-core; KT13-96-53: complete right horn-core (Fig. 2F, G; 3B); KT13-96-93 (Fig. 3D), KT13-96355, KT13-96-459, KT13-96-175 (Fig. 3C): horn-core pieces; KT13-96-67 and KT13-96-442: occipital condyles with parts of the basioccipital; KT13-96-406: m3; KT13-96-231 and KT1396-548: upper molars. KT2-94-16 is a fragment of horn-core which could be of $\underline{\mathrm{K}}$. tchadensis but there is no definite evidence of this species outside KT13.

Etymology--The name tchadensis comes from the French name for Chad.

Diagnosis--A $\underline{\text { Kobus }}$ of large size. Horn-cores strongly divergent, almost straight in their lower part, but curving forwards and slightly inwards at their tips. No transverse ridges. Basal cross section almost circular. Supra-orbital foramina of moderate size. Frontals not hollowed, but supra-orbital canal present. Small post-cornual fossa. Face only moderately bent on the cranial axis (in lateral view, angle between top of braincase and top of muzzle very open). Temporal lines weak. Occipital region rather low and wide, with a semi-circular outline. Small mastoid process present. 
Description--Specimen KT13-96-555 has its horns broken at the base, but the occipital area is more complete than that of the holotype, and surface details are much clearer.

The frontal is elevated between horn-cores, but its anterior part is more horizontal, and the angle between it and the parietal is about $160^{\circ}$; the face is therefore moderately bent on the cranial axis. The mid-frontal suture is rather complicated. The supra-orbital foramen, which is of medium size, opens at the postero-lateral corner of a shallow supra-orbital depression which nearly reaches the midline. A canal connects it to the orbit; the frontal is very thick but several specimens broken at various places show that it is not hollowed.

The brain-case is much wider posteriorly than anteriorly (behind the horns). The temporal lines are weak and not very close to each other. The mastoid is of moderate size. Its upper part, with the mastoid foramen, faces posteriorly, but its lower part faces laterally. It bears a vertical ridge which ends ventrally as a small mastoid process, between a similar-sized post-tympanic process and a flattened paroccipital process much inclined backwards. The occipital is very flat, with both lateral sides in the same plane.

The basioccipital is incomplete on all specimens. The posterior tuberosities are wide, but the bone is flattened in its middle part, with only a shallow central groove, except on KT13-96-7, which has strong antero-posterior lateral ridges.

The holotype and other horn-cores share some similarities with the horn-cores of K. korotorensis: (1) they have no transverse ridges; (2) they have antero-posterior rather than medio-lateral compression; and (3) they show a tendency towards posterior and lateral flattening with a hint of a postero-lateral keel between them, but the cross-section is less triangular than in the other species (compare Fig. 3A-D vs Fig. 3E-I).

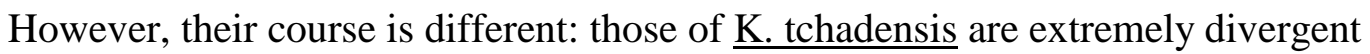

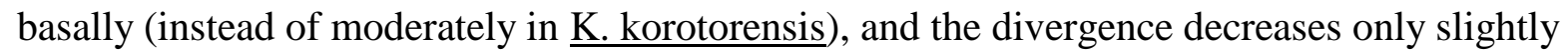
towards the tips (instead of constantly decreasing), which are strongly curved forwards and 
slightly inwards. The basal part is almost straight, very slightly (instead of markedly) curved backwards in most specimens, but slightly forwards in KT13-96-93. None of them shows a sigmoid curvature.

Comparisons--Kobus tchadensis can be compared with North and East African species. It differs from K. khroumirensis (Arambourg, 1979) from the early (?) Pliocene of Garaet Ichkeul in Tunisia, by the lack of transverse compression of horn-cores, their much greater divergence, and the laterally-facing lower part of the mastoid. The Tunisian species is

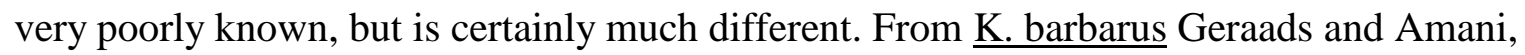
1998, from the late Pliocene of Ahl al Oughlam in Morocco, K. tchadensis differs by its horncores which are much more divergent, much longer and more slender, with decreasing distal divergence, and lack of transverse ridges and of postero-lateral keel.

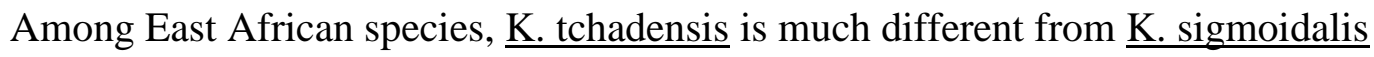
which has weakly divergent, curved and transversely compressed horn-cores. Comparisons

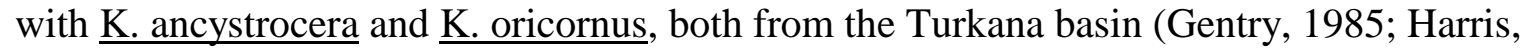
1991) reveal the following shared features with $\underline{\text { K. tchadensis }}$ : (1) strong divergence of horncores, insertions wide apart; (2) very weak or absent basal curvature; (3) forward curvature of tips; (4) small post-cornual fossa; (5) supra-orbital foramina of moderate size; and (6) braincase not much angled on the face.

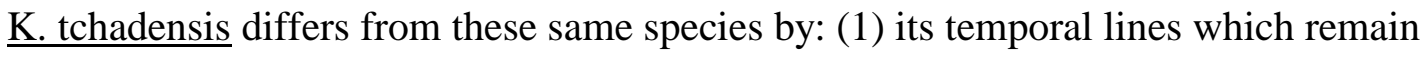
far apart; and (2) the lack of transverse ridges.

It further differs from $\underline{K}$. ancystrocera by: (1) the lack of transverse compression; (2) less strongly recurved tips; (3) pedicle in line with the horn-core proper; (4) less salient orbital rim; (5) shallow groove on the basioccipital of most specimens; and (6) weak temporal lines. However, a horn-core identified as $\underline{\mathrm{K}}$. ancystrocera from Omo member C, L327-2 (Gentry, 1985: 153) is more similar to $\underline{\mathrm{K} . \text { tchadensis }}$ by its flattened posterior surface and lack 
of angle between horn-core and pedicle. Some horn-cores of $\underline{K}$. ancystrocera from Koobi Fora Upper Burgi (Harris, 1991: 169) also have slightly flattened postero-lateral and posteromedial surfaces, with a slight keel between them, and approach the morphology of $\underline{\mathrm{K}}$. tchadensis.

$\underline{K}$. tchadensis differs from $\underline{K}$. oricornus by: (1) its curved instead of almost straight horn-cores; (2) their greater basal divergence, which decreases towards the tips; and (3) the presence of a ridge on the mastoid exposure, which is broader. According to Gentry (1985:

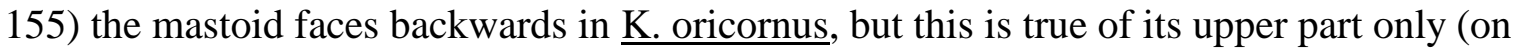
Omo 41-72-1, its lower part faces laterally, as in $\underline{\mathrm{K} . \text { tchadensis}})$.

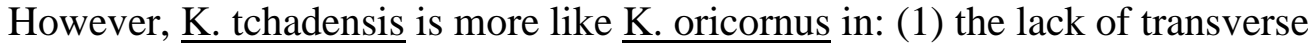
compression (Fig. 4); (2) the lack of pedicle / horn-core angle; (3) the less salient orbital rim; and (4) the weak temporal lines.

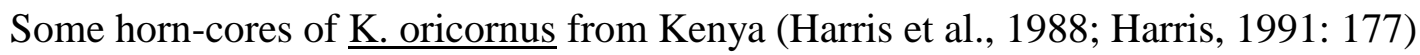
have some forward curvature; thus, their course is more similar to those of $\underline{\mathrm{K} \text {. tchadensis. }}$.

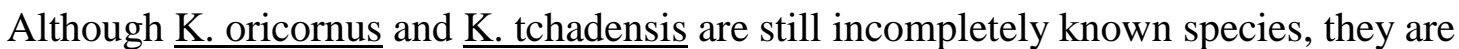
certainly close relatives. We prefer to retain them as separate species because of the differences mentioned above.

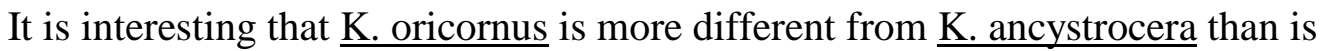
$\underline{K}$. tchadensis. It may be that, in East Africa, the common ancestor of $\underline{K}$. tchadensis and

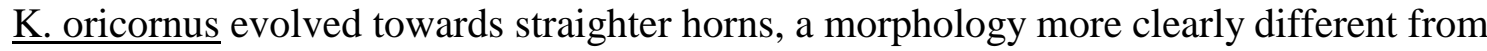

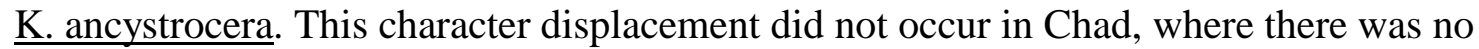
similar species.

Tribe Alcelaphini

Genus Parmularius Hopwood, 1934 
Diagnosis--Gentry and Gentry, 1978: 371

Type-species--Parmularius altidens Hopwood, 1934

$\underline{\text { Parmularius pachyceras }} \mathrm{n} . \mathrm{sp}$.

(Fig. 3O; 5D, E).

Holotype--KT13-96-250: frontlet with part of the orbits and detached partial braincase of the same individual. It was identified as cf. Parmularius nov. sp. in Brunet et al. (1997).

Referred material--KT13-96-19: fragmentary left horn-core; KT13-96-71: base of a left horn pedicle; KT13-95-6, KT13-96-100 and KT13-96-486: distal pieces of horn-cores; KT13-96-506: piece of basi-occipital; several isolated teeth and incomplete tooth-rows; some limb bones. The species is not definitely known outside KT13, but might be present at KT12 and KT33 (see below).

Etymology--From the Greek pachy, thick, and ceras, horn.

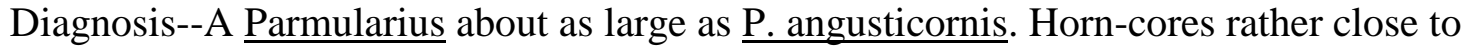
the orbit, weakly divergent, with a weak clockwise torsion. Horn-cores are very thick at the base but without basal swelling, with a tendency towards a flattened posterior face. Their diameters quickly decrease after a sharp backward bend near mid-length. There is no postcornual fossa, the parietal boss is moderate, and the premolar row is short.

Description--The type has been reconstructed from a skull broken into several pieces. Some of them do not fit perfectly, and the horns now appear slightly more divergent than they were in life. The partial braincase cannot be precisely fitted onto the frontlet, but the frontoparietal angle was certainly around $100^{\circ}$. There is a small rounded parietal boss. The base of the horn-cores is much closer to the orbit than in Pleistocene species (i.e. the pedicles are shorter). Details of the bone surface are not clear in this area, but it is almost certain that there was no post-cornual fossa, a rare, if not unique, feature among Parmularius (the post-cornual 


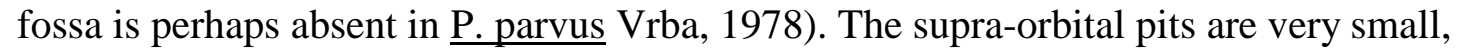
moderately wide apart, and the frontal between them is very slightly concave.

The horn-cores resemble those of $\underline{P}$. ambiguus from the Pleistocene of Tighenif, Algeria (Geraads, 1981) and Aïn Maarouf, Morocco (Geraads and Amani, 1997). The horncores of $\underline{P}$. pachyceras are thick and slightly compressed at the base, with a rounded crosssection, and a tendency towards a flat posterior face. They diverge slightly, and curve abruptly (but not very strongly) backwards near their mid-length. Their diameters strongly diminishes distally. Presence or absence of transverse ridges cannot be determined. There is no clear basal

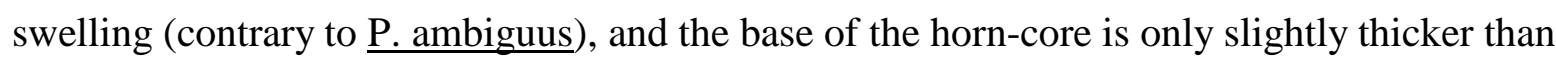
the pedicle.

All alcelaphine horn-cores from KT13 belong to this species; therefore, most of the

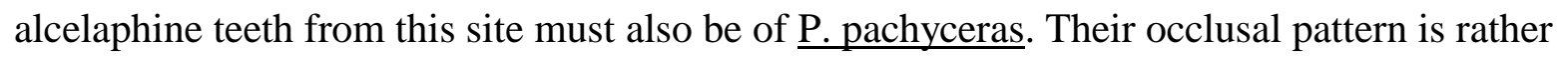
simple. There may be ectostylids on lower molars, but no entostyles on upper ones. Closure of the median valley of p4 occurred rather late in wear. Even though p2 was present on all specimens in which this area is preserved, the premolar row was short, as shown by the following measurements of KT13-98-86: $\mathrm{p} 2-\mathrm{p} 4 \approx 29 ; \mathrm{m} 1-\mathrm{m} 3=67$. This premolar reduction is usual in Parmularius. In contrast, $\underline{P}$. ambiguus had relatively longer premolars, the mean measurements of four complete tooth-rows being : p2-p4 = 29; m1-m3 = 61 (Geraads, 1981).

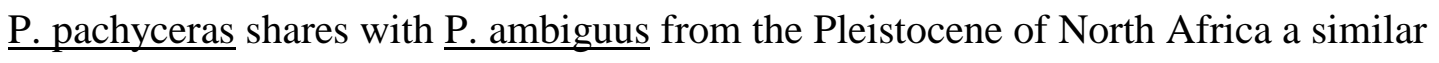
morphology of its horn-cores, but the shorter premolar rows of $\underline{\mathrm{P} . \text { pachyceras, }}$ undoubtedly a

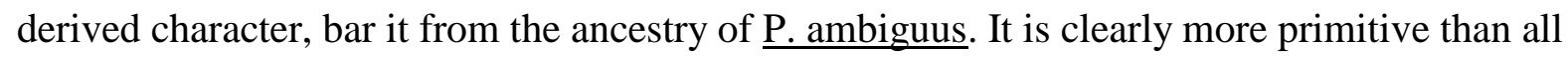
Pleistocene species, including $\underline{P \text {. ambiguus, }}$ by its short pedicles and absence of basal

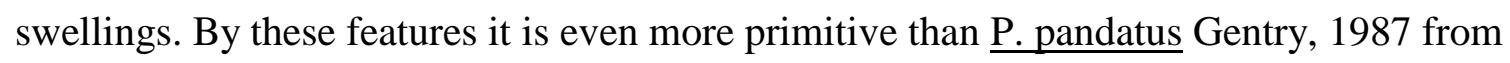
Laetoli and perhaps the late Pliocene of Middle Awash (Vrba, 1997), which has also abruptly bent horn-cores, but the stout horn-cores of $\underline{P}$. pachyceras, with an anterior border more in line 


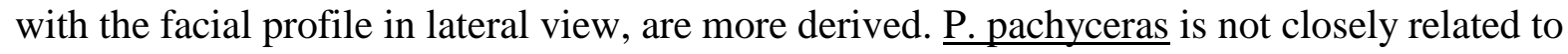
any alcelaphine of similar age, but it is hard to decipher phylogenetic relationships within this genus because, although it is widespread in Africa, only the early Pleistocene $\underline{P \text {. altidens }}$ is well known (Gentry and Gentry, 1978).

The alcelaphine frontlet KT33-96-40 (Fig. 3N; 5A) shares a number of features with P. pachyceras from KT13: (1) short pedicle; (2) basal cross-section of horn-cores rather circular, with a posterior flattening; and (3) slight clockwise torsion of the right horn. The variation of $\underline{P}$. pachyceras being almost unknown, it is hard to tell whether the differences that it displays with the holotype, KT13-96-250, warrant taxonomic distinction. These differences are: (1) smaller size; (2) more regular backward bending and decrease in diameter; (3) presence of transverse ridges; and (4) lesser angle between anterior and posterior parts of the frontal bone (frontal less elevated between horn-cores).

The KT33 frontlet could be from an ontogenically younger specimen than the type, but not from a very young one, because it is already almost as long as the type, and/or it could represent a female. Some of the fragmentary horn-cores from KT13 are more similar to KT3396-40 than is the type (smaller size, less sharp backward bending, presence of transverse ridges) and we prefer to treat all these specimens as belonging to a single variable species (as are, for instance, $\underline{P \text {. ambiguus }}$ or $\underline{P \text {. angusticornis })}$. In any case, it would be unwise to draw any biochronological conclusion from the observed differences.

The only alcelaphine remains from KT12 is an upper tooth series, whose size matches

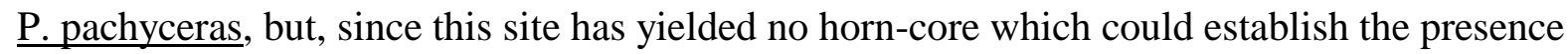
of this species, such an identification would be presumptuous. 
Although KT4b is adjacent to KT4, there is no evidence that the two localities share a single bovid taxon. KT4 has yielded only a few bovid specimens, several of them belonging to an alcelaphine unknown in other localities. It is represented by a frontlet (KT4-94-8; $38.5 \mathrm{x}$ 30.5; width across horn-core pedicles $=81$; Fig. 5B, C, Fig. 3M), the base of a horn-core (KT4-94-5; 44 x 36), a maxilla (KT4-94-18), and two isolated teeth, an m2 (KT4-94-12) and an m3 (KT4-94-11). They may all be of the same individual, but the horn-cores are relatively small, and must represent a female.

The pedicle is hollowed by a single sinus extending into the horn-core. The frontal bone is little bent in the sagittal plane for an alcelaphine, a little less than in the Parmularius from KT33. There is no post-cornual fossa. Horn-cores on the frontlet are rather small and slender. They are slightly curved outwards and backwards and their divergence increases distally. There are strong transverse ridges. The cross section (Fig. 3M) is almost symmetrical, medio-laterally compressed, with a lateral surface slightly less convex than the medial one in the upper part, and the main axis is but slightly inclined on the sagittal plane. Upper teeth are little different from those of KT13, but the buccal lobes of lower teeth are definitely less rounded and the metastylid is better marked. Thus, they have a more primitive aspect.

The weak divergence basally and its steady increase distally are differences with

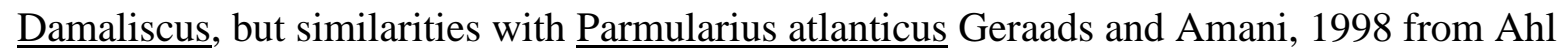
al Oughlam, but this species has horns which are closer to each other, with an incipient common pedicle, and there are no transverse ridges. Damalacra acalla from the Mio-Pliocene of Langebaanweg (Gentry, 1980) has horn-cores with a very similar course, but they have no transverse ridges either. Its teeth are very primitive for an alcelaphine, but those from KT4 are a good morphological intermediate between them and those of more typical Alcelaphines. 
KT13-96-197 and KT13-96-248 are two alcelaphine lower molars which are certainly too small to belong to $\underline{\mathrm{P} . \text { pachyceras}}$, and they must be of another species.

\section{Tribe Antilopini}

Genus Antidorcas Sundevall, 1847

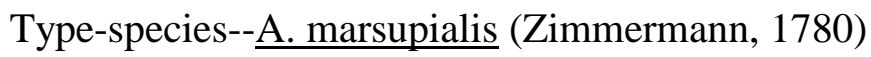

Antidorcas recki (Schwarz, 1932)

Diagnosis--Gentry and Gentry, 1978: 428

Material--KT13-95-7 (Fig. 3L; 5F), KT13-96-176, KT13-96-177: horn-cores; KT1396-433: base of horn-core; a mandible with p2-m2 (KT13-96-222; Fig. 2I), and an upper molar (KT13-96-364), are only doubtfully referred to this species, which is not known outside KT13.

Description--The three larger horn-cores are of similar size, but KT13-96-177 is smaller and shorter, and could be female. They have a clear sigmoid inverse (Oioceros-type) curvature in anterior view, the divergence being weak at the base but increasing distally, as in

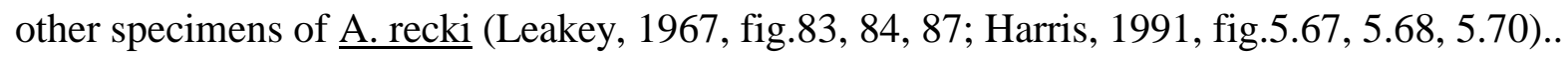
In lateral view, they are uprightly inserted but have a strong and rather sharp curvature backwards. They are not flattened laterally. The supposed female is less strongly bent backwards, but is distinct from Gazella by its sigmoid curvature, deep rounded post-cornual fossa and small sinus in the frontal bone, lateral to the supra-orbital pit, as in the supposed males. The frontal bone is antero-posteriorly bent between the horn bases.

These horn-cores easily fall within the variation range of Antidorcas recki, best known from Olduvai and the Turkana basin. This range is rather large, but in spite of several attempts to link morphological differences with time (Gentry and Gentry, 1978; Harris, 1991), no clear evolutionary trend is recognised in this species, whose earliest record is in the Tulu Bor 
Formation of Koobi Fora, and Omo member B. It is absent from Hadar (Gentry, 1981) and Laetoli (Gentry, 1987).

The incomplete mandible (Fig. 2I) unfortunately lacks m3, so that the length of the third lobe of this tooth and precise premolar / molar proportions are unknown. However, p2 is present and p4 is almost as long as $\mathrm{m} 1$; thus the premolar series is certainly not much reduced (length p2-p4 = 23.2), and p4 is morphologically more like Gazella (Gentry and Gentry, 1978, fig. 32). The main argument against referring it to this latter genus is that the species of Gazella present at KT13 is small, and less common than Antidorcas. It might belong to a larger species of Gazella, but this would imply the co-occurrence of three antilopine species at $\mathrm{KT} 13$, and we prefer to refer it to Antidorcas, an early member of which can be expected to have slightly reduced premolars.

Genus Gazella Blainville, 1816

Gazella sp., cf. G. thomasi Pomel, 1895

The following specimens are incomplete horn-cores of a small gazelle, the first one being of a female. KT13-96-16 (12.2 x 10.9), KT13-96-208 (21.7 x \pm 15.8), KT13-96-284 (- x 17.8) and KT33-96-20 (24.3 x \pm 18.5). KT2-94-13 (26.2 x 19.8) and KT2-96-2 (24.2 x 18.5; Fig. 3K) are probably conspecific, and perhaps of the same species as the one from KT13.

These horn-cores lack torsion, are slightly curved backwards, and rather strongly transversely compressed. They recall both G. praethomsoni Arambourg, 1947 from the Turkana basin, and G. thomasi Pomel, 1895 from the late Pliocene of Algeria and Morocco. Most of the specimens referred to G. praethomsoni (Gentry, 1985; Harris et al., 1988; Harris, 1991, and some unpublished specimens from Omo in the National Museum, Addis Ababa) are more curved but this is not the case of the type-specimen, which seems to differ from the Koro Toro specimens by the great distance between orbit and horn-core. Horn-cores referred to 
G. thomasi from Ahl al Oughlam (Geraads and Amani, 1998) are more similar in this respect. Gentry (1985) assumed that G. praethomsoni was very weakly sexually dimorphic, but Harris et al. (1988) referred two very small horn-cores from West Turkana to this species. If the latter authors were right, then the smaller KT13 horn core might also be a female of this species (Fig. 6).

The Koro Toro specimens are intermediate, both morphologically and geographically,

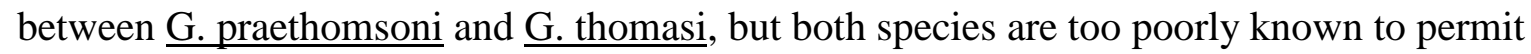
confident referral of the material from Chad to one of them.

The relative abundance of Antidorcas and Gazella is not much different from that of Omo, Koro Toro being indeed the northernmost known occurrence of Antidorcas, which is unknown in North Africa, as in the Palearctic. Koro Toro is clearly Ethiopian in this character.

Bovidae gen. et sp. indet.

Most of the post-cranial material is weathered and fragmentary, and even tribal identification is impossible for most bones. Only some of them are discussed below. Humerus: Two distal epiphysis from KT13 must be of Parmularius pachyceras; they display alcelaphine characters "a - d - e" of Gentry and Gentry (1978, fig. 23). Two other specimens lack these characters; further, their lateral tuberosity is more anterior than in alcelaphines, and they must be reduncine. They are all quite different from tragelaphines, which have a high olecranon fossa, narrow medial condyle, and the distal border of the lateral epicondyle at right angle to long axis of the bone.

Metacarpal-KT13-96-107 is a proximal epiphysis (width 34.3) in which the capitato-trapezoid facet is smaller than in modern alcelaphines, but almost at the same horizontal level as the unciform facet, unlike modern reduncines. Thus, regardless of the tribe to which they belong, they do not display the features of their modern representatives. 


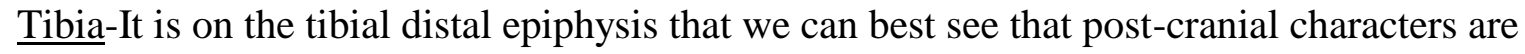
different from those found on present-day African bovids: (1) in distal view, the anterior fibular facet is always more medial than the posterior one, a feature today found only in Hippotragini, a tribe which most of the KT fossils certainly do not belong to; and (2) in front view, the central malleolus is never as broad as in living Alcelaphini, although some of the fossils certainly belong to this tribe. Two specimens even have a pointed central malleolus, unlike all medium-size Recent African bovids; they are especially different from Alcelaphini in this respect, although they are more like this tribe in the well-marked plantar notch (Gentry and Gentry, 1978, fig. 23, character m), and broad plantar part of the medial astragalus facet, like Connochaetes. KT13-96-468 is a complete specimen $(\mathrm{L}=350$; minimum width of shaft $=$ 27.7; distal epiphysis $=42.2 \times 35.6$ ). Definitely none of them belong to the Tragelaphini, which have a extremely broad medial malleolus.

Astragalus-None of them belong to the Tragelaphini, which have a central articular facet, but we were unable to find differences on this bone between Alcelaphini and Reduncini.

Calcaneus-There are 3 complete calcanei. Modern African tribes can best be identified by the size and shape of the sustentaculum tali. In Alcelaphines, it is weak and has a flat inferomedial surface, while it is strong in reduncines, with more distinct medial and inferior faces. All calcanei from KT13 have the sustentaculum weaker than in modern reduncines, but that of the smallest specimen is not so flat as in modern Alcelaphines. If it is a reduncine, which we believe, then the calcanei of both tribes were less different in the Pliocene than they are today. Metatarsal-A complete specimen, KT13-96-41 ( $\mathrm{L}=192$; minimum width of shaft $=14.8)$, is probably reduncine based on its cuboid facet which is sigmoid in profile (rather than concave in Alcelaphines) and its parallel-sided distal epiphysis.

Uncertainties in identifying post-cranial remains are, by themselves, evidence that differences which allow the distinction between Alcelaphini and Reduncini were, in the 
Pliocene, less marked than today. Since the tribal identity of the Koro Toro bovid cranial remains is not questionable, two hypotheses can be drawn. Either the tribal post-cranial characters were acquired within each tribe by parallelism, both among the present-day Alcelaphini and among the Reduncini, or all Recent alcelaphines belong to a monophyletic group not including Parmularius pachyceras and all Recent reduncines belong to a monophyletic group not including the Koro Toro Kobus.

The fact that Parmularius altidens from Olduvai (Gentry and Gentry, 1978: 374-378) has more alcelaphine characters than $\underline{P}$. pachyceras shows that no single explanation is valid for Alcelaphines, but we favour the second hypothesis for reduncines. This lends support to the hypothesis of generic distinction of the Koro Toro reduncine from Kobus.

\section{CONCLUSIONS}

The bovid faunal list by site is provided in Table 6 .

KT13 is the richest site in terms of number of specimens, although it is not rich by East African standards, with less than a hundred bovid fossils identifiable to tribal level. In spite of the relatively low specimen count, the species list is relatively long. Biochronology

The bovids from KT13 do not help much to refine the age of the locality, previously estimated to be 3-3.5 Ma. (Brunet et al., 1997). Cf. Simatherium sp. will perhaps be more useful after better characterisation of the two lineages of African bovines. Kobus korotorensis is more derived than the Kobus from Langebaanweg and Manonga, but is too different from later East and North African species for its evolutionary grade to be compared with theirs.

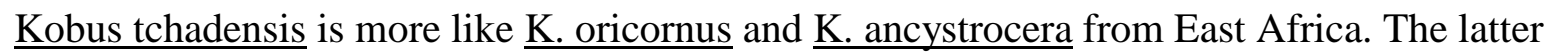
species has a wide stratigraphic range (from Tulu Bor to KBS members at Koobi Fora), but the former is restricted to upper member B of Omo, and the Lokochot and Tulu Bor member 
of Koobi Fora, thus its age ranges from 3.5 to $2.7 \mathrm{Ma}$. The only mentioned reduncines from

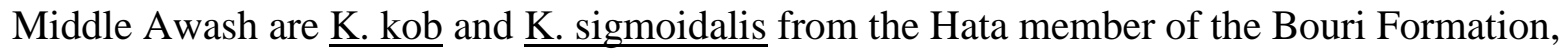
dated to ca. 2.5 Ma. (Heinzelin et al., 1999); these species are certainly unrelated to all those of Koro Toro. From Hadar, Gentry (1981) briefly described a "Kobus sp. A" which is probably close to $\underline{\mathrm{K} \text {. oricornus; }}$ its horn-cores are less clearly antero-posteriorly compressed, and their divergence increases distally, but this species could be at the same stage of evolution as $\underline{\text { K. tchadensis. }}$ Parmularius pachyceras is of rather large size, a derived character, but its short pedicle and lack of horn-core specialisations are primitive. It can be at an evolutionary stage comparable to $\underline{P}$. pandatus from Laetoli and perhaps Wilti Dora 2 in Middle Awash, for which Vrba (1997: 168) favoured an age of 2.7-3.6 Ma. Most of the other Alcelaphines of the Middle Awash (Vrba, 1997) belong to the genera Damalops and Damaliscus; they are certainly absent from Koro Toro. Finally, Antidorcas recki is first known from Omo B and Tulu Bor Formation of Koobi Fora, whose lower limit is about 3.4 Ma. Thus, on the whole, an age range of 2.7 - 3.4 Ma. can be proposed, but not on very firm grounds.

Ecological interpretation

It is well known that the various bovid tribes have different ecological requirements, even though they were perhaps not quite identical in the past. Morpho-functional analysis may provide refinements, but there is little doubt that hypsodont forms like antelopines and alcelaphines were grazers rather than browsers. Thus, analysis of their relative abundance in a fossil locality provides indications about its environment. Vrba (1980) used the ratio of dry open-country grazers (Alcelaphini + Antilopini) to other tribes as an indicator of openness. Other attempts to deduce ecology from anatomy (such as that of Spencer, 1997) yielded basically the same results. At KT13, the total number of identifiable cranial remains is: Alcelaphini $=31 ;$ Reduncini $=22 ;$ Antilopini $=10 ;$ Bovini $=4 ;$ Hippotragini $=1$. Thus, open country grazers largely predominate, although the number of Reduncines show that the 
grasslands were not dry. Reduncines are usually associated with grasslands too wet for trees to grow. Most noticeable is the complete lack (at KT13 as well as in other KT sites) of Aepyceros and Tragelaphini, which today favour bush, thickets or woodlands. All this points to a noticeably poor tree cover in the Koro Toro area. The Bovid fauna of KT13 suggests an environment more open than that of other Middle Pliocene faunas of East Africa (with the exception of Laetoli), and more like those of latest Pliocene and early Pleistocene faunas. Since KT13 is certainly earlier than the latest Pliocene, one must conclude that open landscapes were probably established in Chad earlier than in East Africa. The environment of

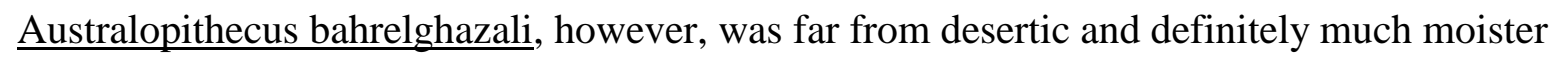
than today, although less so than contemporary Hominid sites in East Africa.

\section{ACKNOWLEDGMENTS}

This research was made possible by the Chadian authorities, Ministère de l'Education Nationale (CNAR and University of N'Djamena) and Ministère des Mines et de l'Energie (DRGM) and was supported by grants from the Ministère français de la Coopération (MCAC N'Djamena), Ministère français de l'Education Nationale, de la Recherche et de la Technologie (CNRS and University of Poitiers), the Groupe Elf and the Association pour le Prix Scientifique Philip Morris. We thank all members of the M.P.F.T expedition and the French Army for logistic support. D. G. also thanks Dr Jara Hailemariam for permission to work in the National Museum, Addis Ababa. The corrections and suggestions of J.Kappelman and of an anonymous reviewer greatly improved the manuscript. 


\section{LITERATURE CITED}

Arambourg, C. 1979. Vertébrés villafranchiens de l'Afrique du Nord (Artiodactyles,

Carnivores, Primates, Reptiles, Oiseaux). Fondation Singer-Polignac, Paris, 141 pp.

Brunet, M., A. Beauvilain, Y. Coppens, E. Heintz, A.H.E. Moutaye, and D. Pilbeam. 1996.

Australopithecus bahrelgazali, une nouvelle espèce d'Hominidé ancien de la région de

Koro Toro (Tchad). Comptes-Rendus de l'Académie des Sciences, IIa 322:907-913.

D. Geraads, F. Guy, M. Kasser, H.T. Mackaye, L.M. MacLatchy, G.

Mouchelin, J. Sudre and P. Vignaud. 1997. Tchad: un nouveau site à Hominidés

Pliocène. Comptes-Rendus de l'Académie des Sciences, IIa 324:341-345.

$\longrightarrow, \ldots, \ldots, \ldots, \ldots$, et al. 1998. Tchad: découverte d'une

faune de Mammifères du Pliocène inférieur. Comptes-Rendus de l'Académie des

Sciences, Sciences de la Terre et des Planètes 326:153-158.

Gentry, A. W. 1967. Pelorovis oldowayensis Reck, an extinct bovid from East Africa. Bulletin of the British Museum (Natural History) Geology 14:243-299.

1978. Bovidae; pp. 540-572 in Cooke, H. B. S. and V. J. Maglio (eds.),

Evolution of African Mammals. Harvard University Press, Cambridge, Mass.

1980. Fossil Bovidae (Mammalia) from Langebaanweg, South Africa. Annals of

the South African Museum 79:213-337.

1981. Notes on Bovidae (Mammalia) from the Hadar Formation and from

Amado and Geraru, Ethiopia. Kirtlandia 33:1-30.

1985. The Bovidae of the Omo group deposits, Ethiopia; pp.119-191 in Les

faunes plio-pléistocènes de la basse vallée de l'Omo (Ethiopie), I: Périssodactyles-

Artiodactyles (Bovidae). CNRS, Paris.

1987. Pliocene Bovidae from Laetoli; pp. 378-408 in M. D. Leakey, and J. M.

Harris (eds.), Laetoli, a Pliocene site in northern Tanzania. Clarendon Press, Oxford. 
, 1997. Fossil Ruminants (Mammalia) from the Manonga Valley, Tanzania;

pp.107-135 in T. Harrison (ed.), Neogene Paleontology of the Manonga Valley, Tanzania. Plenum Press, New York.

, and A. Gentry. 1978. Fossil Bovidae (Mammalia) of Olduvai Gorge, Tanzania.

Bulletin of the British Museum (Natural History) Geology, Part I: 29:289-446, Part II: 30:1-83.

Geraads, D. 1981. Bovidae et Giraffidae (Artiodactyla, Mammalia) du Pléistocène de Ternifine (Algérie). Bulletin du Muséum National d'Histoire Naturelle, 4ème sér., C, $3: 47-86$

, and F. Amani. 1997. La faune du gisement à Homo erectus de l'Aïn Maarouf, près de El Hajeb (Maroc). L'Anthropologie 101:522-530.

and F. Amani. 1998. Bovidae (Mammalia) du Pliocène final d'Ahl al Oughlam, Casablanca, Maroc. Paläontologische Zeitschrift 72:191-205.

, and H. Thomas. 1994. Bovidés du Plio-Pléistocène d'Ouganda. pp.383-407 in:

Pickford M. and B. Senut (eds.), Geology and Palaeontology of the Albertine Rift valley, Uganda-Zaire. II. CIFEG, Publication occasionnelle 29.

Harris, J. M. 1991. Family Bovidae; pp.139-320 in J. M. Harris, (ed.), Koobi Fora research project, 3 : The fossil Ungulates : Geology, fossil Artiodactyls and palaeoenvironments. Clarendon Press, Oxford.

—, J. M., F. H. Brown, and M. G. Leakey. 1988. Stratigraphy and paleontology of Pliocene and Pleistocene localities west of lake Turkana, Kenya. Contributions in Science, Natural History Museum of the Los Angeles County 399:1-128.

Heinzelin, J. de, J. D. Clark, T. White, W. Hart, P. Renne, G. WoldeGabriel, Y. Beyene, and E. Vrba. 1999. Environment and behavior of 2.5-Million-Year-Old Bouri Hominids. Science 284:625-629. 
Leakey, L. S. B. 1967. Olduvai Gorge 1951-1961. Fauna and background. Cambridge Univ. Press, $109 \mathrm{pp}$.

Lehmann, U., and H. Thomas. 1987. Fossil Bovidae (Mammalia) from the Mio-Pliocene of Sahabi, Libya; pp.323-335 in N. T. Boaz, A. El-Arnauti, A. W. Gaziry, J. de Heinzelin, and D. D. Boaz (eds.), Neogene Paleontology and Geology of Sahabi. Alan R. Liss Inc., New York.

Lucas, S. G. 1986. Proper syntax when using aff. and cf. in taxonomic statements. Journal of Vertebrate Paleontology 6:202.

Matthews, S. C. 1973. Notes on open nomenclature and synonymy lists. Palaeontology 16:713-719.

Schneider, J.-L. 1989. Géologie et hydrogéologie de la République du Tchad. Thèse Univ. Avignon, France (unpublished).

Spencer, L. M. 1997. Dietary adaptations of Plio-Pleistocene Bovidae: implications for hominid habitat use. Journal of Human Evolution 32:201-228.

Thomas, H. 1980. Les Bovidés du Miocène supérieur des couches de Mpesida et de la Formation de Lukeino (district de Baringo, Kenya); pp.82-91 in R.E.F. Leakey, and B. A. Ogot (eds.), Proceedings of the 8th Panafrican congress of Prehistory, Nairobi, 1977.

Vrba, E. S. 1980. The significance of bovid remains as indicators of environment and predation patterns; pp.247-271 in A. K. Behrensmeyer, and A. P. Hill (eds.), Fossils in the making. University of Chicago Press. 1987. A revision of the Bovini (Bovidae) and a preliminary revised checklist of Bovidae from Makapansgat. Palaeontologia Africana 26:33-46. 
1997. New fossils of Alcelaphini and Caprinae (Bovidae: Mammalia) from Awash,

Ethiopia, and phylogenetic analysis of Alcelaphini. Palaeontologia Africana 34:127198.

Wells, L.H., and Cooke, H.B.S. 1956. Fossil Bovidae from the Limeworks quarry, Makapansgat, Potgietersrus. Palaeontologia Africana 4:1-55. 
TABLE 1. Comparative skull measurements of $\underline{\mathrm{K} . \text { tchadensis }}$ and $\underline{\mathrm{K} . \text { ancystrocera. }}$

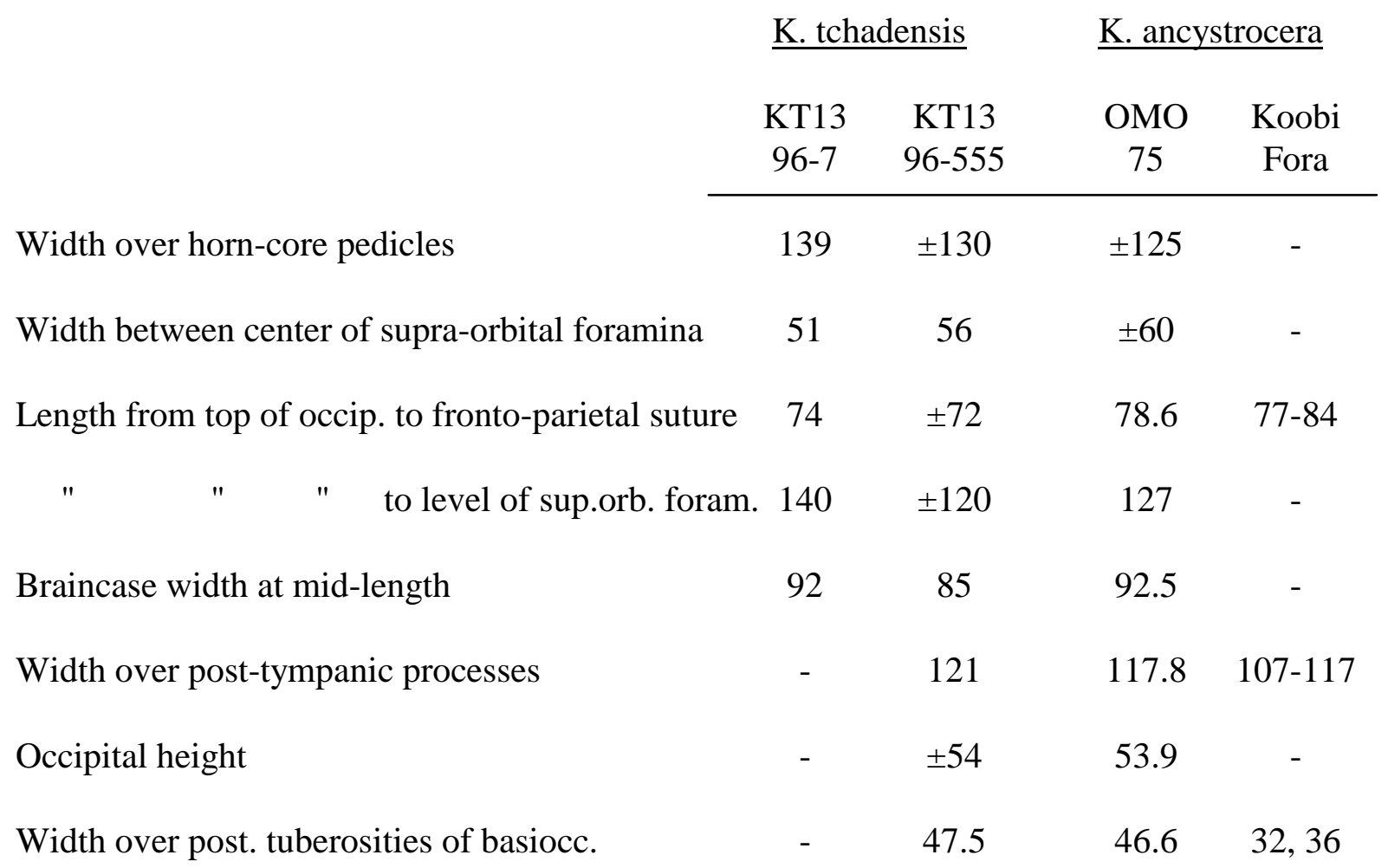




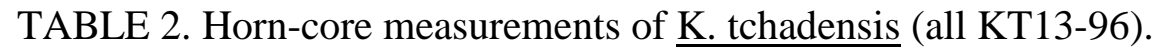

\begin{tabular}{lcccccc}
$\mathrm{N}^{\circ}$ & 7 & 355 & 53 & 93 & 175 & 555 \\
\hline Basal horn-core diameters & $54.5 \times 55.5$ & $39 \times 46.5$ & $58 \times 54$ & $46.5 \times 46$ & $38.5 \times 42$ & $44.5 \times 43$ \\
Divergence angle & $110^{\circ}$ & $\pm 100^{\circ}$ & $\pm 100^{\circ}$ & - & $\pm 90^{\circ}$ & -
\end{tabular}

Length along anterior curve $\quad \pm 460 \quad-\quad \quad \quad \pm 430$ 


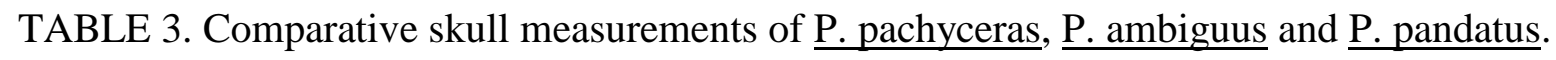

\begin{tabular}{lcccc} 
& KT13-96-250 & KT33-96-40 & $\underline{\text { P. ambiguus }}$ & P. pandatus \\
\cline { 2 - 5 } Basal horn-core (HC) diameters & $56 \times 51$ & $39.5 \times 38.5$ & $48-63 \times 37-50$ & $43.8 \times 38.2$ \\
Width across HC pedicles & $117-( \pm 110)$ & \pm 105 & $105-130$ & 92.8 \\
Width between supra-orbital pits & 57 & $\pm 2 \times 30$ & 58,70 & 45.7 \\
Length of HC along anterior curve & $\approx 200$ & $\approx 195$ & $175-210+$ & 208 \\
Brain-case width at mid-length & \pm 83 & - & - & 73.8
\end{tabular}


TABLE 4. Horn-core measurements of Antidorcas recki.

\begin{tabular}{lcccc} 
& KT13-95-7 & KT13-96-176 & KT13-96-177 & KT13-96-433 \\
\cline { 2 - 5 } Basal horn-core diameters & $49 \times 24$ & $30.3 \times 23.5$ & $26.5 \times 20.2$ & $30.3 \times 22.5$ \\
Length along anterior curve & \pm 142 & $135 ?$ & \pm 95 & -
\end{tabular}


TABLE 5. Measurements of humeri.

Alcelaphini KT13-95-9 distal articular width 43.5 mini. articular diameter (A-P) 23.9

KT13-96-74

45.5

24

Reduncini KT13-96-75

44.5

23.4

KT13-96-249

44.5

24.8 
TABLE 6

Bovid list by locality

$\begin{array}{llllll}\text { KT2 } & \text { KT4 } & \text { KT4b } & \text { KT12 } & \text { KT13 } & \text { KT33 }\end{array}$

cf. Simatherium sp.

Hippotragini gen. and sp.indet.

Kobus korotorensis

$\underline{\text { Kobus tchadensis }}$

$\mathrm{cf}$

$+\quad+\quad+$

$\underline{\text { Parmularius pachyceras }}$

cf $\quad+$

cf

aff. Damaliscus sp.

$+$

Alcelaphini indet.

$\underline{\text { Antidorcas recki }}$

$\underline{\text { Gazella }}$ cf. G. $\underline{\text { thomasi }}$ 
FIGURE 1. Map of the Koro Toro area, Chad, with the position of the localities discussed in this paper. Redrawn from Schneider, 1989.

FIGURE 2. A, Bovini gen. et sp. indet., cf Simatherium, p4-m2 KT13-96-207. B-C, Kobus korotorensis, holotype, left horn-core KT13-95-8 in (B) medial and (C) antero-superior views; D-E, Kobus korotorensis ?, frontlet KT12-98-06 in (D) lateral and (E) anterior views. F-G, Kobus tchadensis, right horn-core KT13-96-53 in (F) superior and (G) medial views; H, Kobus tchadensis, holotype KT13-96-7, frontlet in anterior view. I, Antidorcas recki, tooth-row p2-m2. Scale bar equals $3 \mathrm{~cm}$ for A, $6 \mathrm{~cm}$ for B-E, $10 \mathrm{~cm}$ for F-H, $2 \mathrm{~cm}$ for I.

FIGURE 3. Cross-sections of horn-cores, all taken at the base, except E which is $5 \mathrm{~cm}$ above the base. All drawn as if from the right side and seen from above. Medial side is to the left, anterior side to the top of the page. A-D, Kobus tchadensis. E-I, Kobus korotorensis; J, Kobus korotorensis ?. K, Gazella sp., cf. G. thomasi. L, Antidorcas recki. M, aff. Damaliscus sp. N, Parmularius pachyceras ?; O, Parmularius pachyceras. Scale bar equals $5 \mathrm{~cm}$.

FIGURE 4. Plot of transverse vs. antero-posterior diameters of $\underline{\mathrm{K} . \text { tchadensis }}$ horn-cores compared with those of $\underline{\mathrm{K}}$. ancystrocera and $\underline{\mathrm{K} \text {. oricornus }}$ from the Turkana basin (ranges of variation of the transverse and antero-posterior diameters are indicated for 29 specimens of $\underline{K}$. ancystrocera from Omo G).

FIGURE 5. A, Parmularius pachyceras ?, frontlet KT33-96-40, anterior view. B-C, aff. Damaliscus sp., frontlet KT4-94-8, in (B) anterior and (C) lateral views. D-E, 
Parmularius pachyceras, frontlet KT13-96-250, holotype, in (D) anterior and (E) lateral views. F, Antidorcas recki, horn-core KT13-95-7 in lateral view. Scale bar equals $10 \mathrm{~cm}$ for $\mathrm{F}, 15 \mathrm{~cm}$ for all others.

FIGURE 6. Plot of transverse vs antero-posterior diameters of Gazella sp., cf. G. thomasi horn-cores, compared with those of G. praethomsoni from the Turkana basin, and G. thomasi from North Africa. 